\title{
SUITABILITY OF SANDS FROM DIFFERENT LOCATIONS AT NSUKKA AS BACKFILL MATERIAL FOR VIBROFLOTATION
}

\author{
J. H. Pogu ${ }^{1,}$, C. C. Okafor ${ }^{2}$ and J. C. Ezeokonkwo ${ }^{3}$

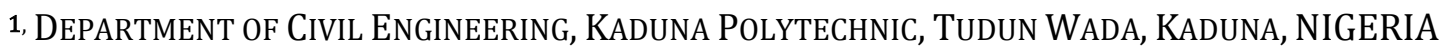 \\ 2,3, DEPARTMENT OF CIVIL ENGINEERING, UNIVERSITY OF NIGERIA NSUKKA, NIGERIA \\ Email addresses:1 joshuapogu@gmail.com, ${ }^{2}$ chigozie.okafor@unn.edu.ng, ${ }^{3}$ josephat.ezeokonkwo@unn.edu.ng
}

\begin{abstract}
Soil stabilization using vibroflotation method requires material backfill for smooth operation of the process and effective densification. Backfill materials fill the voids created by the vibroflot and acceptable backfill is sand with less percentage of fines. This study assesses the suitability of Nsukka sand for backfill purpose in vibroflotation. Samples of Nsukka sand were tested in the laboratory for their physical, mechanical and electro-chemical properties. The suitability numbers $\left(S_{N}\right)$ were determined and a linear regression analysis carried out to correlate the values of $S_{N}$ with the properties of the sand. Tests results showed that Nsukka sand is "Good" backfill material for vibroflotation with a mean $S_{N}$ of 15 . The samples indicated narrow percentage of fines value of $0.34-4.81 \%$ and are generally classified as poorly graded sand (SP) with mean fineness modulus of 2.12. They have low salt content with electrical conductivity values between $1090-1950 \mu \mathrm{S} / \mathrm{cm}$ and mean $\mathrm{pH}$ and chloride content values of 6.8 and 98.5ppm respectively. Dry compaction test reveals mean MDD value of $1809 \mathrm{~kg} / \mathrm{m}^{3}$ for standard Proctor compaction. Linear regression analysis reveals that $S_{N}$ is dependent on $D_{10}$ and $D_{30}$. The efficiency of the model was tested with separate results and the differences between the actual and the predicted $S_{N}$ were small and acceptable. This study concludes that Nsukka sand is a good material for vibroflotation densification.
\end{abstract}

Keywords: Backfill Material, Nsukka Sand, Regression Analysis, Suitability Number, Vibroflotation.

\section{INTRODUCTION}

Vibroflotation is a mechanical means by which loose deposits of cohesionless soils are densified using special vibrators called vibroflot. The process enhances engineering properties of soil deposit of thickness of up to $70 \mathrm{~m}$ deep. The deep vibratory energy of the vibroflot helps improve the properties of the soil with regards to reduction in compressibility and settlements, as well as increase in strength and relative density [1], [2] and [3]. The densification of the soil is enhanced by in-andout movement of the vibroflot in the sand deposit with massive vibratory energy which effectively shakes the sand to a denser state. This creates an opening called crater to be backfilled. The opened crater is usually backfilled with suitable material like sand or blast furnace slag. Zepada and McCreery [4] explained that "the gradation of the backfill is the most important factor controlling the speed at which the backfill reaches the void created by the vibroflot". Brown [5] developed an empirical equation to rate the suitability of sands for the purpose of backfill in vibroflotation. The equation developed (shown in equation 1) linked the suitability of sands for vibroflotation to their suitability number $\left(\mathrm{S}_{\mathrm{N}}\right)$, which in turn depends on the grain size distribution, $\mathrm{D}_{50}, \mathrm{D}_{20}$ and $\mathrm{D}_{10}$. Where $\mathrm{D}_{50}, \mathrm{D}_{20}$ and $\mathrm{D}_{10}$ are respective diameters $(\mathrm{mm})$ through which 50,20 , and $10 \%$ of the material passes. Suitability number is given by:

$$
S_{N}=1.7 \sqrt{\frac{3}{\left(D_{50}\right)^{2}}+\frac{1}{\left(D_{20}\right)^{2}}+\frac{1}{\left(D_{10}\right)^{2}}}
$$

Table 1: Interpretation of Brown's Suitability Numbers

\begin{tabular}{cccccc}
\hline Range of Suitability Number $\left(\mathrm{S}_{\mathrm{N}}\right)$ & $0-10$ & $10-20$ & $20-30$ & $30-50$ & $>50$ \\
\hline Rating as Backfill & Excellent & Good & Fair & Poor & Unsuitable \\
\hline
\end{tabular}


The use of vibrators to compact granular soil at a depth dates back to around 1930's in Germany when Russian Sergei Stervermann and Wilhelm Degen proposed the compaction of cohesionless soil below and above the water table $[1,6]$. The two men came to a conclusion that the best way to get a deposit of granular soil densified is by having the vibrator taken to a depth where horizontal emitted forces from the vibrator can be in direct contact with the soil. Griffith [2] stated that even though the two men were to be separated to different countries as a result of the political upheavals of 1930's in Germany, both men went ahead to produce poker vibrators based on a similar theory which has been used for vibroflotation. In the United States it was first used in 1948 when the Bureau of Reclamation studied the possibilities for sand and silt compaction at the site of the Enders Dam in Nebraska [7].

A remarkable early application of vibroflotation was also undertaken when the US Navy wanted to build Trident Atlantic Coast Strategic Submarine Base in 1976. The objective at Trident project was to reduce the risk of future settlement and liquefaction potential to the underlying soil. Therefore, deep soil stabilization was chosen as an alternative to exclusive deep foundation design. The vibration from the probe was expected to overcome the inter-angular frictional force of loose cohesionless soils and cause them to "flow by gravity into a dense state" [2, 8].

Recently, vibroflotation has gained acceptance globally as an economical means of deep soil improvements where deposits of cohesionless soil pose uncertainty. The other choice is deep foundation design and construction, a method that is both expensive and technically demanding. Vibroflotation success has been attested to in many places around the world including Nigeria [9 - 11].

Emmanuel and Ikechukwu [12] worked on the "Suitability of Umuahia Sand as Backfill Materials for Vibroflotation Compaction of Cohesionless Soils". Their conclusion was that Umuahia sand is an "excellent" backfill material in vibroflotation based on Brown [5] rating system. However, their work did not correlate the suitability number to the various geotechnical properties of Umuahia sand.

This paper reports on the suitability of Nsukka sand as backfill material in vibroflotation. Samples of sand from different locations in Nsukka were evaluated for their suitability numbers. The objective of the study is to correlate the suitability numbers of the sand samples to their measured geotechnical properties using linear regression analysis. This will help build a model with suitability number considered as dependent variable and the other measured properties as independent variables. The goal is to draw up a relationship that will be used to characterize the suitability of Nsukka sand for the purpose of vibroflotation backfill.

\section{MATERIALS AND METHODS}

\subsection{Location of the Study Area}

Nsukka LGA has an estimated area of $1,810 \mathrm{~km}^{2}$ and is located on a geographical coordinates of $6^{0} 51^{\prime} 24^{\prime} \mathrm{N}$ and 7023'45'E. It is a town and Local Government Headquarters in Southeast Nigeria, Enugu state [13].

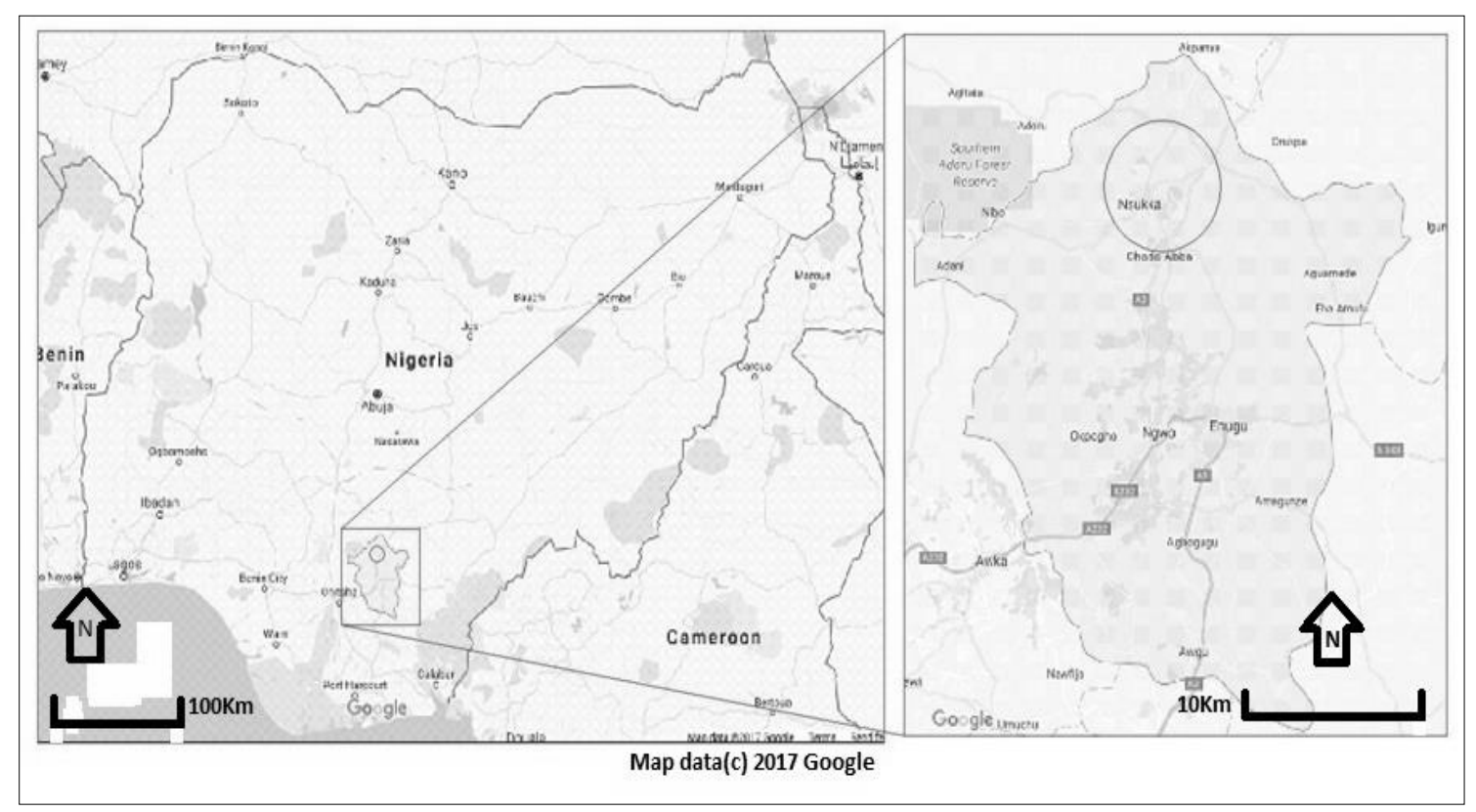

Figure 1: The Map of the Study Area 


\subsection{Sampling Procedure}

A total of eight samples were collected at Opi, Obimo and Nkpologu communities of Nsukka. The borrow pits are located outside the various communities. About $25 \mathrm{~kg}$ of sand sample was collected at each borrow pit for testing.

The colours of the samples of sand vary from reddish brown to white. All the samples were collected at a depth of about $1.5 \mathrm{~m}$ to $5.0 \mathrm{~m}$. The site at Opi spans over many kilometers with various borrows pits. Three samples were taken from there at a lateral distance of about $300 \mathrm{~m}$ in-between collection pits. The sand samples were scrapped down from the exposed strata to the floor and packaged into each polythene bag and labeled accordingly. At Obimo, three samples were collected at different borrow pits. The samples were taken from the surplus on the floor of the pits using shovel. Two additional samples, from different pits were collected at Nkpologwu borrow pits in a similar way.

The samples collected were transported to Civil Engineering Department laboratory, University of Nigeria Nsukka where they were tested in accordance with the procedures set out in BS 1377 of 1990 to determine their physical, mechanical and electrochemical properties for use as backfilling material in vibroflotation. Portion of the samples were also taken to Civil Engineering Laboratory, Kaduna Polytechnic for further testing using the same procedure in BS 1377 (1990).

These samples of sand from different locations in Nsukka were evaluated for their suitability numbers and other geotechnical properties. In engineering and science, regression analysis is extensively used to study the relationship between two or more variables. This study seeks to establish relationship between suitability number and other properties of Nsukka sand. This will ultimately result in building models with properties of the sand considered as either dependent or independent variables [14].

\subsection{Experimental Procedures}

The laboratory tests carried out on the specimens collected were all in accordance with the procedures described in BS 1377 (1990) [15]. These tests are specifically listed as follows:

Classification tests (Sieve analysis, particle density): BS 1377-2: 1990

Compaction-related tests (Standard and Modified) BS 1377-4: 1990
Chemical and Electro-chemical tests $(\mathrm{pH}$, Electrical conductivity and water soluble chloride content)

BS 1377-3: 1990

Angle of repose was determined based on Fixed Funnel Method commonly described in many literatures.

\subsection{MODEL FORMULATION}

\subsubsection{Single Linear Regression Analysis}

SPSS was used to characterize the suitability of Nsukka sand for vibroflotation from its measured properties by using single and multiple linear regression analyses. The general representation of a probabilistic single and multiple linear regression models are usually presented in the following forms:

$$
\begin{gathered}
Y=\beta_{0}+\beta_{1}+\varepsilon \\
Y=\alpha_{0}+a_{1} x_{1}+\alpha_{2} x_{2} \ldots+\alpha_{n} x_{n}+\varepsilon
\end{gathered}
$$

Where, the slope $\left(\beta_{1}\right)$ and intercept $\left(\beta_{0}\right)$ of the single linear regression model are called regression coefficients. Likewise, coefficients $\alpha_{0}, \alpha_{1}, \alpha_{2}$ and $\alpha_{\mathrm{n}}$ are termed multiple regression coefficients. The appropriate way to generalize this to a probabilistic linear model is to assume that the actual value of $\mathrm{Y}$ is determined by the mean value function (the linear model) plus the random error term, $\varepsilon$, [14]. The best single linear regression model in this work has a coefficient of determination value of 0.918 for the variable $\mathrm{D}_{10}$. This necessitated the use of multiple regression equations which were better at predicting the variance in suitability number of Nsukka sand since they have higher values of coefficients of determination.

\subsubsection{Multiple Regressions}

In many practical instances, a variable may depend on more than one independent variable and hence, multiple regressions become useful. Many variables were used to determine the relationship between suitability number and other properties of Nsukka sand in this study. However, the best model arising from these combinations is represented in equation (4) with $\mathrm{R}^{2}$ value as high as 0.981 . This equation, which relates $S_{N}$ to $D_{10}$ and $D_{30}$, was adopted since it predicts to a higher degree of accuracy, the variance in suitability number of Nsukka sand.

$$
\text { Model A: } S_{N}=39.04 D_{10}-27.70 D_{30}+29.89
$$

\section{RESULTS AND DISCUSSION}

\subsection{Materials Classification and Description}

Table 2 shows the classification of the sand samples analysed in this paper. The sand samples were 
classified as SP according to Unified Soil Classification System (USCS). The shapes of the particle size distribution curves are generally smooth as indicated in Figure 2. As presented on the Figure, several researchers have suggested "bandwidth" or "suitability zones" for materials to be effectively densified by vibroflotation procedure [3], [5] and [8]. Table 2 presents some index properties of Nsukka sand which were obtained from particle size distribution analysis. These include Fineness Modulus (FM), coefficient of uniformity $\left(\mathrm{C}_{U}\right)$ and coefficient of gradation. The $\mathrm{C}_{U}$ values are well above 2 , which means that the samples are not uniform sand. The range of values of $C_{U}$ falls within the limits specified as $2.2-6.8$ as required for use in vibroflotation by design manuals like NAVFAC DM 7.3 and other researchers [3], [8] . The higher the value of $\mathrm{C}_{U}$ the larger the range of particle sizes in the soil. The values of fineness modulus of the samples range between 1.66 and 2.67. This affirms that the samples are either fine sand or medium sand.

\subsection{Suitability of Nsukka Sand as Backfill Material in Vibroflotation}

Table 3 shows the suitability number $\left(\mathrm{S}_{\mathrm{N}}\right)$ of samples of Nsukka sand and their ratings. Nsukka sand is suitable for backfill in vibroflotation. A sample from Obimo was rated as "Excellent". A similar study conducted on Umuahia Sand by [13] found out that Umuahia sand is "excellent" backfill material for vibroflotation. This suggests that Anambra basin have types of sand that are generally suitable as backfill material for vibroflotation purposes. Table 3 also indicated that the total fines content in Nsukka sand samples range between $0.34-4.81 \%$. This figure falls within acceptable value of less than $6 \%$ according to Glover [1, 11] for sand used as backfill in vibroflotation.

Table 2: Samples Classification and Description

\begin{tabular}{|c|c|c|c|c|c|c|}
\hline \multirow[t]{2}{*}{ Sample No. } & \multirow[t]{2}{*}{ \% Passing No. 200 Sieve } & \multirow{2}{*}{$\begin{array}{l}\text { Fineness } \\
\text { Modulus }\end{array}$} & \multirow{2}{*}{$\begin{array}{l}\text { Coefficient of } \\
\text { Uniformity }\end{array}$} & \multirow{2}{*}{$\begin{array}{l}\text { Coefficient of } \\
\text { Gradation }\end{array}$} & \multicolumn{2}{|c|}{ Classification (USCS) } \\
\hline & & & & & $\begin{array}{l}\text { Group } \\
\text { Symbol }\end{array}$ & Group Name \\
\hline OPI-I & 2.93 & 2.23 & 2.57 & 1.34 & SP & \\
\hline OPI-II & 1.22 & 2.29 & 3.03 & 1.14 & SP & $\frac{n}{z}$ \\
\hline OPI-III & 4.81 & 1.66 & 2.68 & 1.13 & SP & $\overline{\tilde{S}}$ \\
\hline NKPO.-I & 1.52 & 1.93 & 2.75 & 1.45 & SP & $\bar{Q}$ \\
\hline NKPO.-II & 1.43 & 2.42 & 2.92 & 1.16 & SP & $\underset{\pi}{\pi}$ \\
\hline OBIMO-I & 2.20 & 1.85 & 3.09 & 0.93 & SP & $\begin{array}{l}\overrightarrow{0} \\
\vec{\lambda}\end{array}$ \\
\hline OBIMO-II & 0.34 & 1.88 & 2.54 & 0.90 & SP & $\vec{a}$ \\
\hline OBIMO-III & 1.17 & 2.67 & 2.38 & 0.85 & SP & $\stackrel{0}{2}$ \\
\hline
\end{tabular}

USCS: Unified Soil Classification System

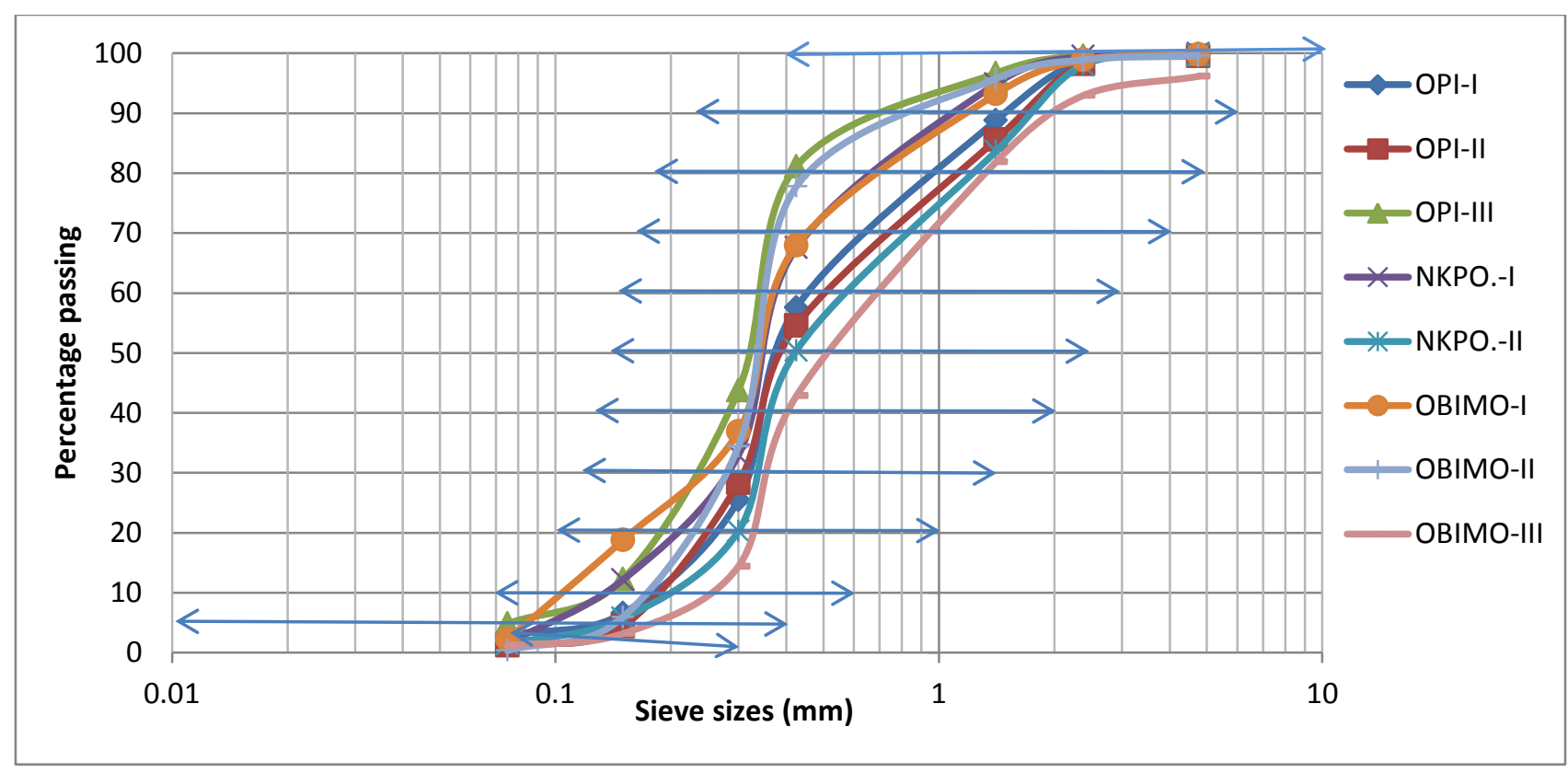

Figure 2: Particle Size Distribution Curves of sand samples from Nsukka 
Figures 3 show $\mathrm{S}_{\mathrm{N}}$ of Nsukka sand as correlated to $\mathrm{D}_{10}$, $D_{30}, D_{50}$ and $D_{60}$. However, the degree of correlation is highest when $\mathrm{S}_{\mathrm{N}}$ is related to $\mathrm{D}_{10}$ with $\mathrm{R}^{2}$ as high as 0.918 . In other words the predictor, $\mathrm{D}_{10}$ alone accounts for about $91.8 \%$ of the variance in $\mathrm{S}_{\mathrm{N}}$.

\subsection{Descriptive Statistics}

Table 4 gives a statistical summary of the results of the tests carried out on Nsukka sand. The strength and electro-chemical parameters have all indicated weaker relationship with $S_{N}$. Hence, emphasis was on the grain size characteristics only.

Table 3: Suitability Rating of Nsukka Sand

\begin{tabular}{llllllll}
\hline $\begin{array}{l}\text { Sample } \\
\text { No. }\end{array}$ & $\begin{array}{l}\text { Suitability } \\
\text { Number }\end{array}$ & Rating & $\mathrm{D}_{10}(\mathrm{~mm})$ & $\mathrm{D}_{30}(\mathrm{~mm})$ & $\mathrm{D}_{50}(\mathrm{~mm})$ & $\begin{array}{l}\mathrm{D}_{60} \\
(\mathrm{~mm})\end{array}$ & $\begin{array}{l}\text { Fines } \\
(\%)\end{array}$ \\
\hline OPI-I & 14 & GOOD & 0.175 & 0.325 & 0.370 & 0.450 & 2.93 \\
OPI-II & 14 & GOOD & 0.175 & 0.325 & 0.400 & 0.530 & 1.22 \\
OPI-III & 18 & GOOD & 0.138 & 0.240 & 0.325 & 0.370 & 4.81 \\
NKPO-I & 17 & GOOD & 0.140 & 0.280 & 0.350 & 0.385 & 1.52 \\
NKPO.-II & 13 & GOOD & 0.185 & 0.340 & 0.425 & 0.540 & 1.43 \\
OBIMO-I & 20 & GOOD & 0.118 & 0.200 & 0.315 & 0.365 & 2.20 \\
OBIMO-II & 14 & GOOD & 0.185 & 0.280 & 0.440 & 0.470 & 0.34 \\
OBIMO-III & 10 & EXCELLENT & 0.260 & 0.370 & 0.475 & 0.620 & 1.17 \\
\hline
\end{tabular}

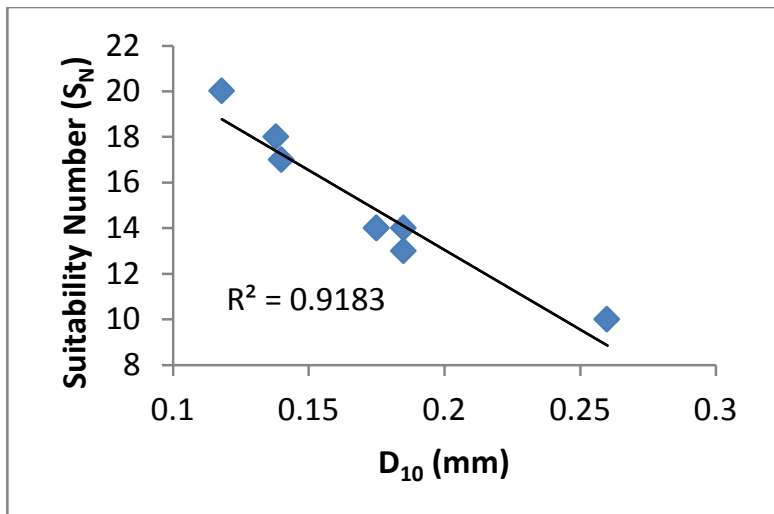

Figure 3(a): Relationship between $S_{N}$ and $D_{10}$

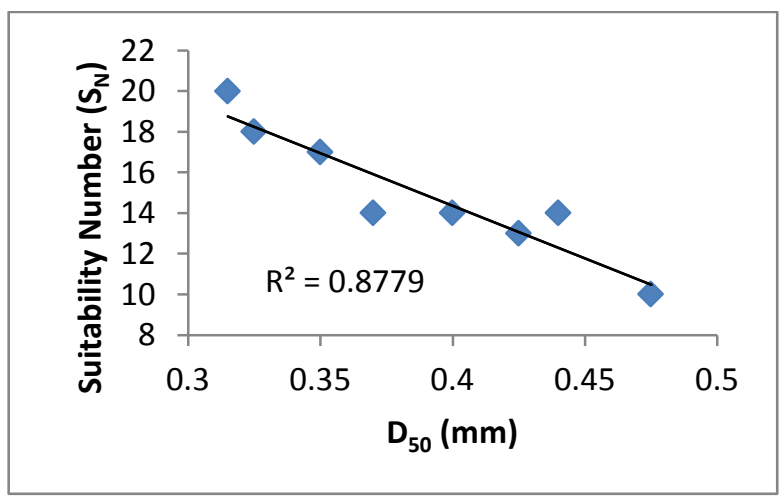

Figure 3(c): Relationship between $S_{N}$ and $D_{50}$

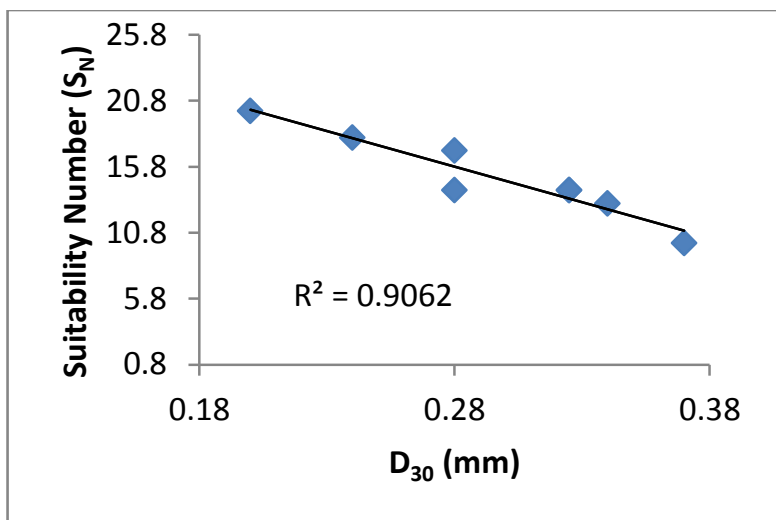

Figure 3(b): Relationship between $S_{N}$ and $D_{30}$

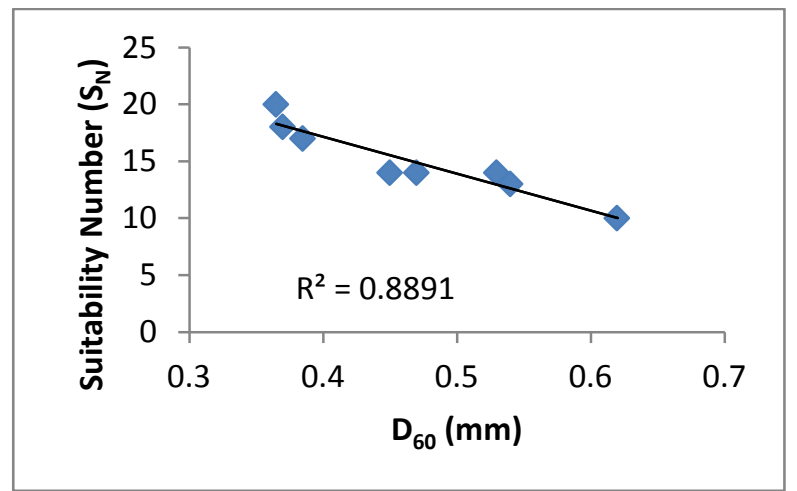

Figure 3(d): Relationship between $S_{N}$ and $D_{60}$

Table 4: Descriptive Statistics

\begin{tabular}{llllllll}
\hline \multicolumn{1}{c}{ Variables } & Units & Minimum & Maximum & Mean & $\begin{array}{c}\text { Std. } \\
\text { Deviation }\end{array}$ & $\begin{array}{c}\text { Coefficient of } \\
\text { Variation (COV) }\end{array}$ & Variance \\
\hline $\mathrm{S}_{\mathrm{N}}$ & - & 10 & 20 & 15.00 & 3.162 & .2108 & 10.000 \\
$\mathrm{D}_{10}$ & $(\mathrm{~mm})$ & .118 & .260 & .17200 & .043418 & .25243 & .002 \\
$\mathrm{D}_{20}$ & $(\mathrm{~mm})$ & .160 & .340 & .23750 & .061340 & .258274 & .004 \\
$\mathrm{D}_{30}$ & $(\mathrm{~mm})$ & .200 & .370 & .29500 & .055997 & .18982 & .003 \\
$\mathrm{D}_{50}$ & $(\mathrm{~mm})$ & .315 & .475 & .38750 & .057134 & .147443 & .003 \\
\hline
\end{tabular}




\begin{tabular}{|c|c|c|c|c|c|c|c|}
\hline Variables & Units & Minimum & Maximum & Mean & $\begin{array}{c}\text { Std. } \\
\text { Deviation }\end{array}$ & $\begin{array}{c}\text { Coefficient of } \\
\text { Variation }(\mathrm{COV})\end{array}$ & Variance \\
\hline $\mathrm{D}_{60}$ & $(\mathrm{~mm})$ & .365 & .620 & .46625 & .092224 & 197799 & .009 \\
\hline $\mathrm{Gm}$ & - & 1.15 & 1.63 & 1.3750 & .15547 & .113069 & .024 \\
\hline FM & - & 1.68 & 2.67 & 2.1163 & .34050 & .160894 & .116 \\
\hline$\%<425 \mu \mathrm{m}$ & (\%) & 42.83 & 81.13 & 62.4725 & 13.39042 & .214341 & 179.303 \\
\hline$\%$ Fines & (\%) & .34 & 4.81 & 1.9525 & 1.38312 & .708384 & 1.913 \\
\hline$C_{U}$ & - & 2.38 & 3.09 & 2.7450 & .25100 & .091439 & .063 \\
\hline $\mathrm{C}_{\mathrm{C}}$ & - & .85 & 1.45 & 1.1125 & .21259 & .191092 & .045 \\
\hline EC & $(\mu \mathrm{S} / \mathrm{cm})$ & 1090 & 1950 & 1433.75 & 268.325 & .187149 & 71998.214 \\
\hline $\mathrm{pH}$ & - & 6.6 & 7.1 & 6.838 & .1506 & .022024 & .023 \\
\hline$\varphi$ & $\left({ }^{0}\right)$ & 24.9 & 32.2 & 28.938 & 2.9914 & .103373 & 8.948 \\
\hline $\mathrm{G}_{\mathrm{S}}$ & - & 2.5500 & 2.7200 & 2.62500 & .0515475 & .019637 & .003 \\
\hline $\begin{array}{l}\text { MDD } \\
\text { STANDARD }\end{array}$ & $\left(\mathrm{g} / \mathrm{cm}^{3}\right)$ & 1.765 & 1.876 & 1.80938 & .036951 & .020422 & .001 \\
\hline $\begin{array}{l}\text { MDD } \\
\text { MODIFIED }\end{array}$ & $\left(\mathrm{g} / \mathrm{cm}^{3}\right)$ & 1.765 & 1.976 & 1.85513 & .073147 & .03943 & .005 \\
\hline $\mathrm{Cl}^{-}$ & $(\mathrm{ppm})$ & 78.1 & 120.7 & 98.513 & 14.4202 & .146379 & 207.941 \\
\hline
\end{tabular}

$\mathrm{Gm}=$ grading modulus, $\mathrm{FM}=$ Fineness modulus, $\mathrm{C}_{\mathrm{U}}=$ coefficient of uniformity, $\mathrm{C}_{\mathrm{C}}=$ coefficient of curvature, $\mathrm{EC}=$ electrical conductivity, $\varphi=$ angle of repose, $\mathrm{G}_{S}=$ specific gravity, $\mathrm{MDD}=$ maximum dry density.

\subsection{Regression Analyses}

Table 5 shows the influence of one variable on the other. Correlation coefficients and their level of significance were determined. Already it was found that the strength and electro-chemical parameters have all indicated weaker relationship with $S_{\mathrm{N}}$. In Table 5, correlation matrix has already established a strong relationship between suitability number and other properties of Nsukka sand with some at a significance level of 0.01 and 0.05 . These properties had indicated higher correlation coefficients individually and were selected for multiple linear regression analyses based on that. Equation (4) which was selected, provides strongest relationship in terms of higher coefficient of determination in predicting the suitability number of Nsukka sand. However, other multiple regression analyses were carried out with some having more than two independent variables. The following equations present some of the multiple regression analyses carried out and their coefficients of determination in descending order.

Model A:

$S_{N}=39.04 D_{10}-27.70 D_{30}+29.89 ; R^{2}=0.981$

Model B:

$$
\begin{array}{r}
S_{N}=36.28 D_{10}-26.41 D_{30}-2.13 D_{60}+.30 .02 ; \\
R^{2}=0.981
\end{array}
$$

$$
\begin{array}{r}
S_{N}=4.20 D_{20}-26.69_{30}-27.72 D_{60}+34 . .62 ; \\
R^{2}=0.976
\end{array}
$$

Model D:

$S_{N}=30.66 D_{30}-15.68_{60}+31.35 ; R^{2}=0.948$

Model E:

$S_{N}=43.69 D_{10}-13.24 D_{60}+28.99 ; R^{2}=0.939$

Model F:

$$
\begin{array}{r}
S_{N}=12.22 D_{10}-16.21_{20}-32 . .16 D_{50}+33.42 \\
R^{2}=0.935
\end{array}
$$

\subsection{Validation of the Regression Equation}

Model A, given in equation (4) was selected for further verification and validation among the other models because of its least standard error and it is simple and predicts $\mathrm{S}_{\mathrm{N}}$ within the $95 \%$ confidence level. This means that the predictors $\mathrm{D}_{10}$ and $\mathrm{D}_{30}$ account for more than $98 \%$ of the variance in $\mathrm{S}_{\mathrm{N}}$ with a p-value of $5.2 \mathrm{E}$ 05. In order to validate this equation, similar test results for five different samples were obtained from Reynolds Construction Company (RCC). Table 6 compares actual and predicted values of $\mathrm{S}_{\mathrm{N}}$. The residual values are much smaller. The relationship shown in Figure 4 demonstrates clearly that the developed equation is statistically valid; and that the equation can be used for preliminary characterization of $S_{N}$ for Nsukka sand as backfill material for vibroflotation.

Model C: 
Table 5: Correlation Matrix of Pearson Correlation Coefficients

\begin{tabular}{|c|c|c|c|c|c|c|c|c|c|}
\hline \multicolumn{6}{|l|}{ Pearson } & \multicolumn{4}{|l|}{$\%$} \\
\hline Correlation & $\mathrm{S}_{\mathrm{N}}$ & $\mathrm{D}_{10}$ & $\mathrm{D}_{30}$ & $\mathrm{D}_{50}$ & $\mathrm{D}_{60}$ & $<425 \mu \mathrm{m}$ & $\%$ Fines & $\mathrm{C}_{\mathrm{U}}$ & $\mathrm{Cl}^{-}$ \\
\hline \multirow[t]{2}{*}{$\mathrm{S}_{\mathrm{N}}$} & 1 & $-.958^{* *}$ & $-.952^{* *}$ & $-.937^{* *}$ & $-.943^{* *}$ & $.719^{*}$ & .499 & .560 & $.734^{*}$ \\
\hline & & .000 & .000 & .001 & .000 & .044 & .208 & .149 & .038 \\
\hline \multirow[t]{2}{*}{$\mathrm{D}_{10}$} & $-.958^{* *}$ & 1 & $.861^{* *}$ & $.927^{* *}$ & $.928^{* *}$ & -.692 & -.458 & -.639 & $-.726^{*}$ \\
\hline & .000 & & .006 & .001 & .001 & .057 & .254 & .088 & .042 \\
\hline \multirow[t]{2}{*}{$\mathrm{D}_{30}$} & $-.952^{* *}$ & $.861^{* *}$ & 1 & $.813^{*}$ & $.895^{* *}$ & $-.809^{*}$ & -.415 & -.431 & $-.710^{*}$ \\
\hline & .000 & .006 & & .014 & .003 & .015 & .307 & .286 & .049 \\
\hline \multirow[t]{2}{*}{$D_{50}$} & $-.937^{* *}$ & $.927^{* *}$ & $.813^{*}$ & 1 & $.919^{* *}$ & -.585 & -.686 & -.505 & -.662 \\
\hline & .001 & .001 & .014 & & .001 & .128 & .060 & .202 & .074 \\
\hline \multirow[t]{2}{*}{$D_{60}$} & $-.943^{* *}$ & $.928^{* *}$ & $.895^{* *}$ & $.919^{* *}$ & 1 & $-.814^{*}$ & -.551 & -.321 & -.586 \\
\hline & .000 & .001 & .003 & .001 & & .014 & .156 & .438 & .127 \\
\hline \multirow[t]{2}{*}{$\%<425 \mu \mathrm{m}$} & $.719^{*}$ & -.692 & $-.809^{*}$ & -.585 & $-.814^{*}$ & 1 & .389 & .052 & .542 \\
\hline & .044 & .057 & .015 & .128 & .014 & & .340 & .903 & .166 \\
\hline \multirow[t]{2}{*}{$\%$ Fines } & .499 & -.458 & -.415 & -.686 & -.551 & .389 & 1 & .017 & .559 \\
\hline & .208 & .254 & .307 & .060 & .156 & .340 & & .967 & .150 \\
\hline \multirow[t]{3}{*}{$C_{U}$} & .560 & -.639 & -.431 & -.505 & -.321 & .052 & .017 & 1 & .649 \\
\hline & .149 & .088 & .286 & .202 & .438 & .903 & .967 & & .082 \\
\hline & $.734^{*}$ & $-.726^{*}$ & $-.710^{*}$ & -.662 & -.586 & .542 & .559 & .649 & 1 \\
\hline $\mathrm{Cl}^{-}$ & .038 & .042 & .049 & .074 & .127 & .166 & .150 & .082 & \\
\hline
\end{tabular}

**. Correlation is significant at the 0.01 level (2-tailed).

*. Correlation is significant at the 0.05 level (2-tailed).

Table 6: Validation of Regression Analysis Equation

\begin{tabular}{llllll}
\hline Sample No. & $\mathrm{D}_{10}(\mathrm{~mm})$ & $\mathrm{D}_{30}(\mathrm{~mm})$ & Actual $\mathrm{S}_{\mathrm{N}}$ & Predicted $\mathrm{S}_{\mathrm{N}}$ & Residual \\
\hline Obimo sand & 0.230 & 0.380 & 11.288 & 10.385 & 0.9033 \\
Eke sand & 0.178 & 0.320 & 13.465 & 14.077 & -0.6116 \\
Enugu Rd Sand I & 0.161 & 0.269 & 15.409 & 16.153 & -0.7439 \\
Enugu Rd Sand II & 0.148 & 0.256 & 16.341 & 17.021 & -0.6798 \\
Obollo sand & 0.180 & 0.335 & 13.206 & 13.583 & -0.3778 \\
\hline
\end{tabular}

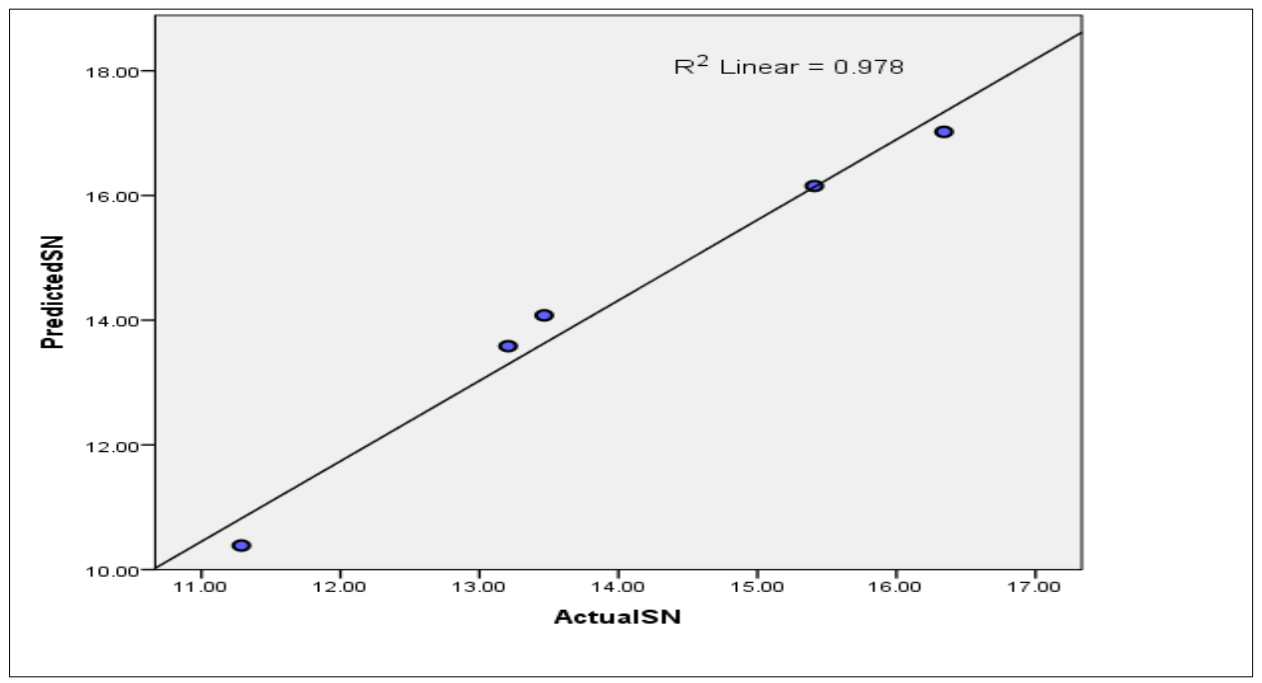

Figure 4: Relationship between Predicted $S_{N}$ and Actual $S_{N}$

\section{CONCLUSION}

The following conclusions are drawn from the study.

Nsukka sand samples have indicated fines content of $0.34-4.81 \%$ and can generally be classified as poorly graded sand (SP) by Unified Soil
Classification System. They are considered to be "Good" material for backfill purposes in vibroflotation. The samples of the sand analysed have indicated a mean suitability number $\left(\mathrm{S}_{\mathrm{N}}\right)$ of 15. A model which relates $S_{N}$ with effective size 
$\left(D_{10}\right)$ and $D_{30}$ was developed using multiple linear regression, and the model was tested and found to be reliable. Grain size characteristics were found to correlate better with $S_{N}$ than other properties of the sands.

\section{RECOMMENDATIONS}

1. Nsukka sand is "Good" for backfill in vibroflotation as such they should be used for this purpose.

2. This study should be repeated with large sample points across the South-Eastern region of Nigeria for better understanding and comparative study. This can be undertaken with regards to vibroflotation or their suitability for other purposes in civil engineering applications.

3. It has been shown that the difference between the actual and predicted values of $\mathrm{S}_{\mathrm{N}}$ is statistically acceptable. However, for practical purposes, model A should only be used when the predicted values of $\mathrm{S}_{\mathrm{N}}$ do not differ by $4.83 \%$ less or $8 \%$ more, otherwise detail analysis should be carried out.

\section{REFERENCES}

[1] Glover, J. C., "Sand Compaction and Stone Columns by Vibroflotation Process", Proceeding of ASCE Symposium on Recent Developments in Ground Improvement Techniques, Bangkok, 29 Nov - 3 Dec, 1982, pp39-51.

[2] Griffith, C. J., "Soil Improvement through Vibrocompaction and Vibro-replacement", Report byUniversity of Maryland for DTIC, Report No. 9201520, 1991.

[3] Balachowski, L. and Kurek, N., "Deep Compaction Control of Sandy Soils", Studia Geotechnica et Mechanica, Vol. 36, No. 2, pp 3-9, 2014.

[4] Zepada, Y. and McCreery, I., "A Review of Vibroflotation for Ground Improvement", http://geoengineer.org/education/web-basedclass-projects/select-topics-in-groundimprovement/vibroflotation?showall=1\&limitsta $\underline{\mathrm{rt}}=$, Accessed on March13, 2017.
[5] Brown, E., "Vibroflotation Compaction of Cohesionless Soils", Journal of Geotechnical Engineering Division ASCE, Vol. 103, No.12, , pp1437-1451,1977.

[6] Holtz, R. D., Konvacs, W. D. and Sheahan, T. C., An Introduction to Geotechnical Engineering, Pearson Prentice Hall, New Jersey, 2011.

[7] D'Appolonia, E., "Loose Sands - Their Compaction by Vibroflotation", Symposium on Dynamic Testing of Soils, Atlantic City, New Jersey,1July, pp138-162, 1954.

[8] Massarsch, K. R. and Fellenius, B. H., "Vibratory Compaction of Coarse-grained Soils", Canadian Geotechnical Journal, Vol. 39, No. 3, pp695-709, 2002.

[9] Mitchell, J. K., "Soil Mechanics and Foundation Engineering", Proceedings of the 10 th ICSMFE, Stockholm, Sweden, June 15 - 19, pp56-68, 1981.

[10] Maschinen, B. G., "Ground Improvement by Depth Vibrator",http://pdf.directindustry.com/bauermaschinen-gmbh/ground-improvement-depthvibrator/, Accessed on April 13, 2017.

[11] Vibroflotation and Geotechnical (Nig.) Limited, "Vibroflotation", $\quad$ http://www.vibroflotationng.com/about/, Accessed on February 17, 2017.

[12] Emmanuel, A. E. and Ikechukwu, E. C. "Suitability of Umuahia Sands as Backfill Materials for Vibroflotation Compaction of Cohesionless Soils", Electronic Journal of Geotechnical Engineering, Vol. 19, pp8977-8982, 2014.

[13] Nsukka. "In Wikipedia, the Free Encyclopedia" https://en.wikipedia.org/w/index.php?title=Nsu kka\&oldid=781613841, Accessed on May 22, 2017.

[14] Montgomery, D. C. and Runger, G. C., Applied Statistics and Probability for Engineers, John Wiley \& Sons Inc., Paperback, New York, 2013.

[15] BS 1377 (1990). British Standard Methods of Test for Soils for Civil Engineering Purposes, British Standard Institution, Printed by Gray Lord and Sons Ltd, London, 1990. 